\title{
Robertsonian translocation in a Chianina cow and in its offspring (1)
}

\author{
M. SILVESTRELLI *, D. CASCIOTTI *, F. VALFRE *, U. CHICCHINI ** \\ * Institute of Animal Production, and **Institute of Veterinary Obstetrics \\ of the University of Perugia \\ Via S. Costanzo 4, 06100 Perugia, Italy
}

\begin{abstract}
Summary
Cytogenetic examination was performed on a thirteen year old Chianina cow which had normal fertility and above average frequency of twin births; the same examination was performed on its offspring. Structural chromosome abnormalities were found in the mitotic cells analyzed.

The aberrations, including the $1 / 29$ translocation, were found in the cow as well as in both sexes of its twin calves which also showed leukocytic chimerism 59XX/59XY.
\end{abstract}

Cytogenetic studies are assuming great importance in studies of subfertility and infertility in animal species of zootechnic interest, particularly cattle and swine.

Frequently, cattle with alterations in reproductive functions show a high incidence of structural abnormalities of an autosome or X-chromosome (HALNAN, 1972 ; EL-NAHASS et al., 1974 ; BongSo \& BASRUR, 1976) or a combination of both.

According to EL-NAHASs et al. (1976) these abnormalities are less common in A.I. bulls and breeding cows than in slaughter cattle. Recently HaNADA \& MurAMATSU (1980) demonstrated a high frequency of structural abnormalities of X-chromosome in a Japanese Black cow with low fertility.

In autochthonous Italian bovine breeds, SUCCI et al. (1976) found, contrary to reports by EL-NaHASS, a high frequency of translocations in bulls of those breeds that also have the highest incidence of sub-fertility, such as the Romagnola breed. Since the bovine Chianina breed has also problems of fertility as a result of long post-partum and calving intervals (about 14-16 months), we took a great interest in

(1) Work supported by the "Progetto Finalizzato - Difesa delle Risorse genetiche delle popolazioni animali » of the C.N.R., subproject II ; O.U. Valfré, C.N.R. grant $\mathrm{n}^{\circ}$ 80.00176/80. The authors participated equally on this work ( $P^{r} F$. Valfré). 

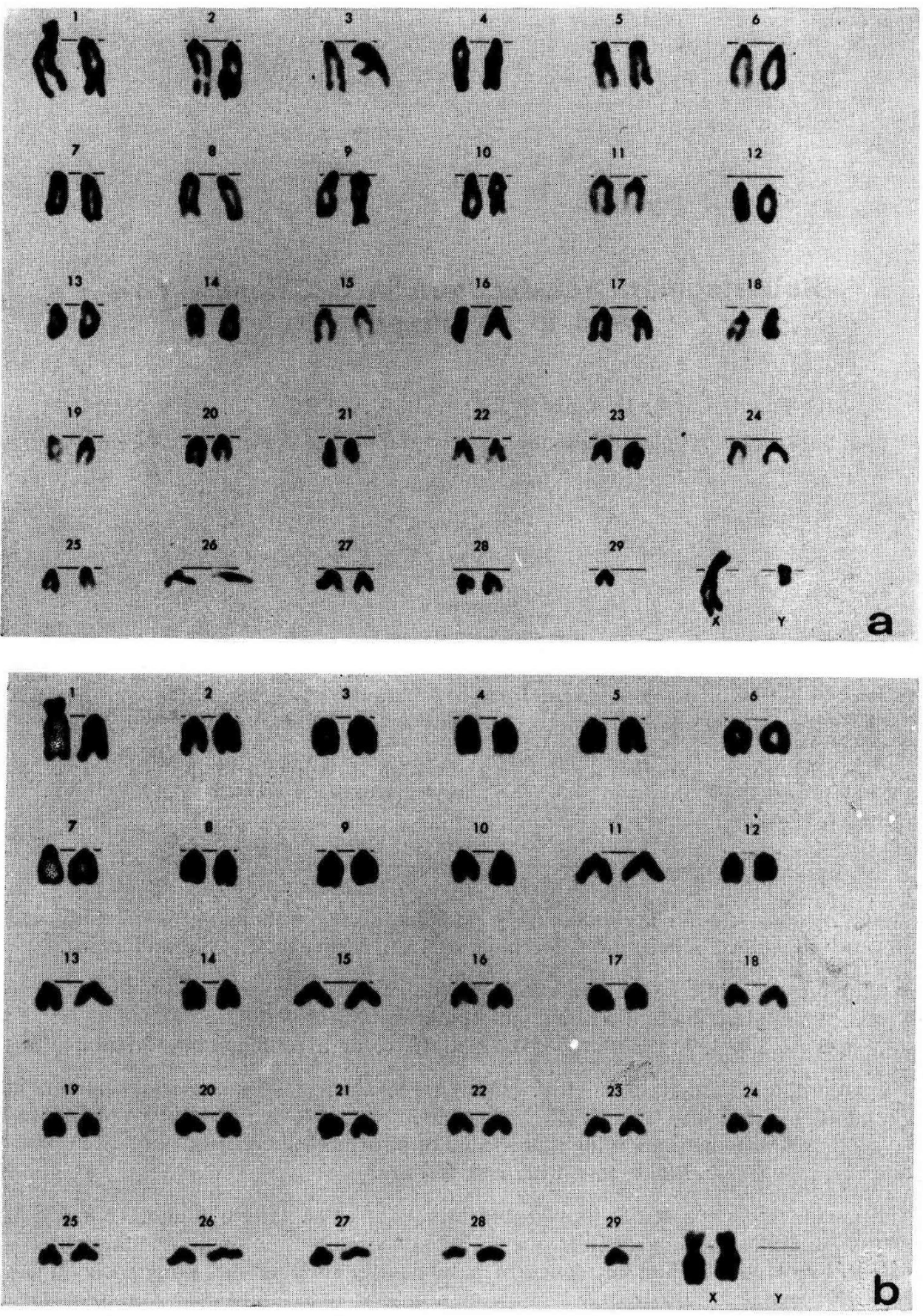

FIG. 1

Karyotype of the male calf with $1 / 29$ translocation

a) $59 \mathrm{XY}$.

Caryotype du veau mâle avec la translocation $1 / 29$

b) $59 \mathrm{XX}$. 

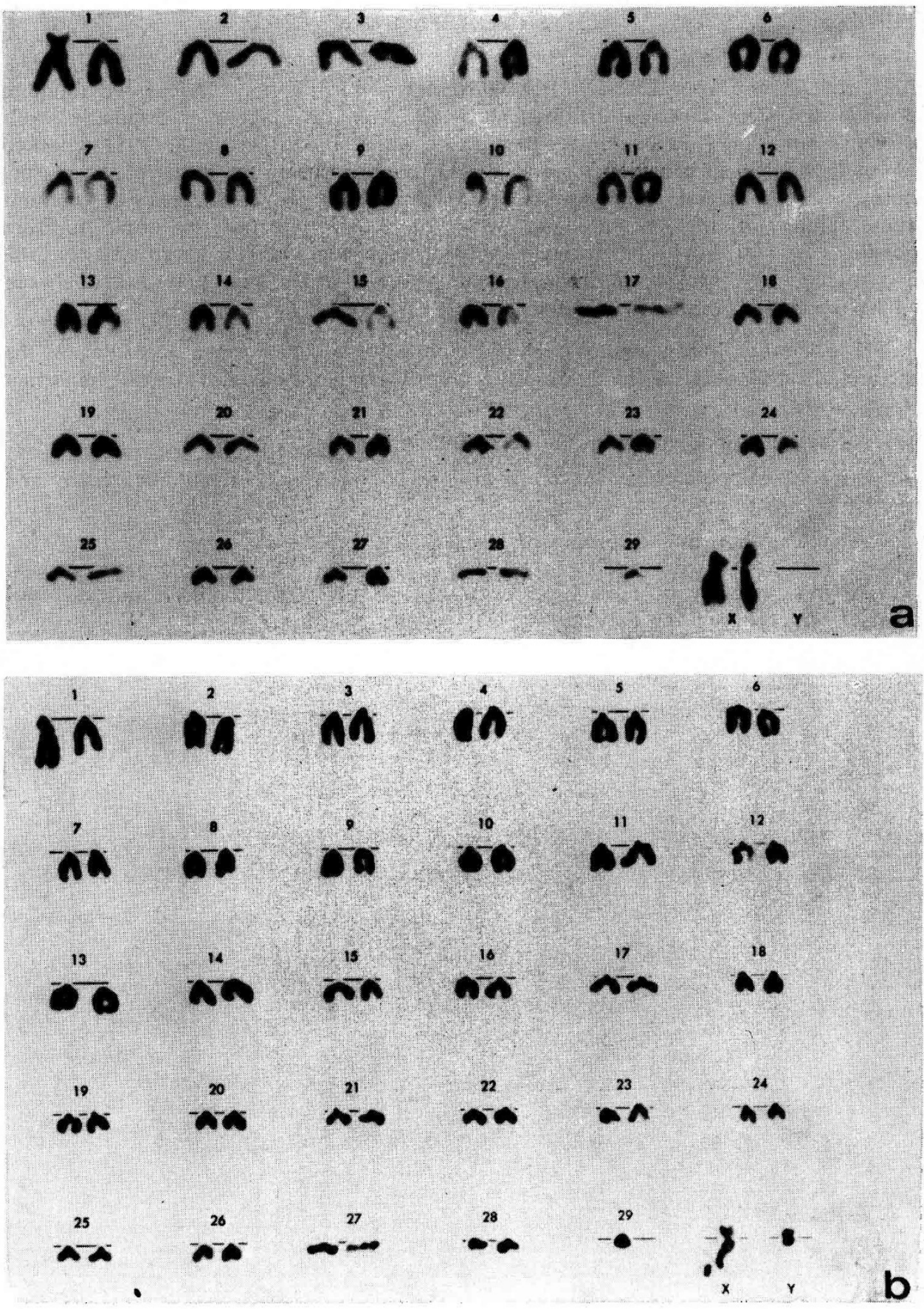

FIG. 2

Karyotype of the female calf with 1/29 translocation

a) $59 \mathrm{XX}$.

Caryotype du veau femelle avec la translocation $1 / 29$

b) $59 \mathrm{XY}$. 
this problem and approached it from different points of view. Indeed we found a positive and significant correlation (CASCIOTTI et al., 1980) between haematic levels of $\mathrm{Cu}^{++}$and $\mathrm{PGF}_{2 \alpha}$ in a subfertile cow. In the same breed Borti et al. (1981) checked the endocrinological behaviour of the post-partum, measuring the levels of the plasma hormones. On several subjects of the Chianina breed we are screening structural abnormalities of the chromosomes with the karyotypic test in order to find possible correlations with hormones involved in reproduction. This karyotypic research is also meant to provide informations on the relationship that may exist between environment and chromosomal aberrations.

The karyotypic test employs cellular cultures and is performed according to the method of DE GRouchY et al. (1964) using whole peripheral blood. The most important stages are :

- careful blood drawing and sedimentation; fixation ;

- culture preparation, arrest of mitoses by colcemid, hypotonic shock and

- preparation and colouring of smears.

A great number of metaphases for each subject was examined and the best samples were chosen for the karyotypic test.

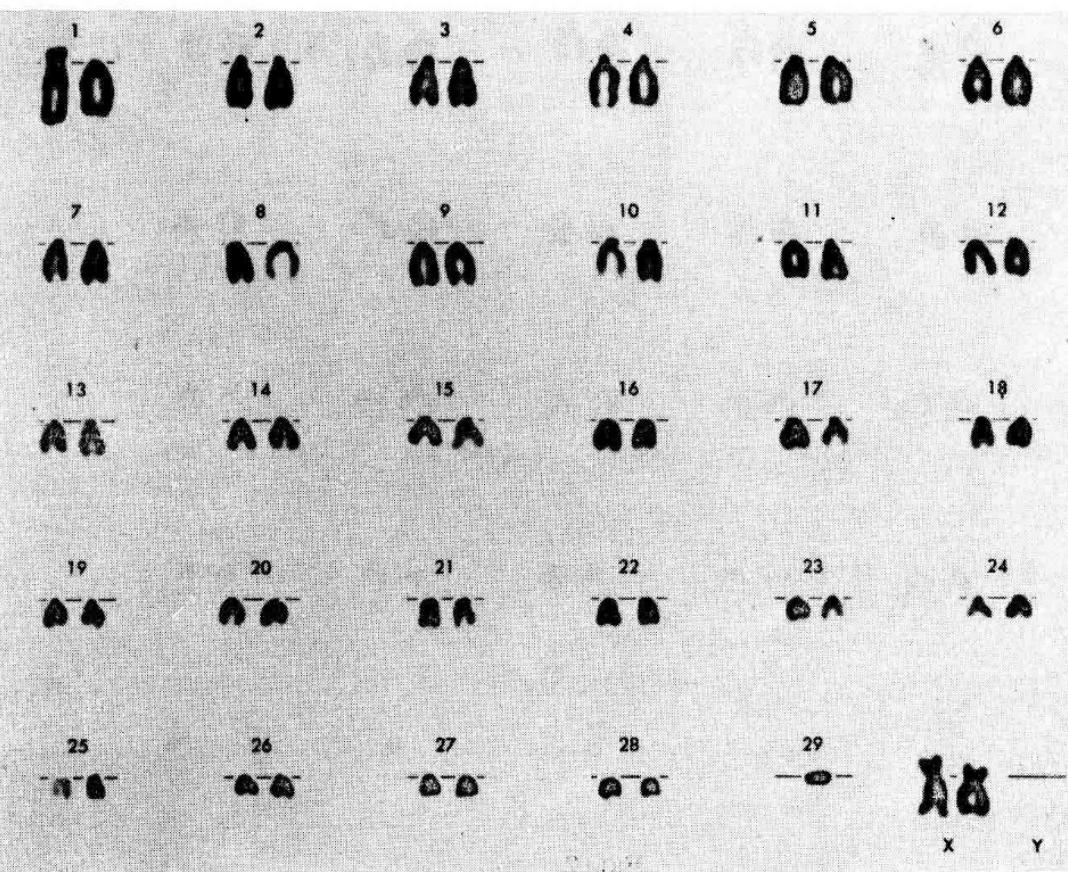

Fig. 3

Karyotype of the Chianina cow with $1 / 29$ translocation

Caryotype de la vache Chianine avec la translocation 1/29 
For the necessary comparisons, female subjects with normal reproductive cycles were compared to others with long calving intervals.

In the group of normal fertility subjects used as a control, a Chianina cow attracted our attention. It was a 13 year old animal with normal fertility, not selected and characterized by an abnormal frequency of twin-births and always with living and viable offspring. During the observation, the cow was six months pregnant and also had the twin calves from its last birth, a male and a female. These animals underwent karyotypic test as well. It should be noted that all three had no particular phenotypical manifestations.

Karyotypic test of the 3 subjects (see pictures no. 1,2,3) revealed the following :

a) the cow :

$-1 / 29$ translocation;

b) the twin calves :

- the same $1 / 29$ translocation as in the cow was present in both;

- true presence of leukocytic chimerism and a chromosomal make up, $59 \mathrm{XX} / 59 \mathrm{XY}$, in both calves.

The chromosomal abnormality is conspicuous in the cow as well as in both sexes of the calves of the last twin birth. Translocation, however, did not cause the cow any fertility disorder. For this reason no conclusion can be drawn. Hormonal research on calves is presently being carried out and the course of the cow's pregnancy will continue to be supervised and its future offspring examined.

Reçu pour publication en octobre 1981.

\section{Résumé}

\section{Translocation robertsonienne chez une vache Chianine et sa descendance}

Une étude cytogénétique a été réalisée chez une vache appartenant à la race Chianine de treize ans. Elle montre une fertilité normale, n'est pas sélectionnée et elle est caractérisée par une certaine fréquence de mises bas gémellaires.

On a fait la même étude cytogénétique chez deux jumeaux, de sexes différents, que la vache avait eu dans la dernière mise en bas. Aussi bien la vache que les jumeaux sont phénotypiquement normaux. Chez la vache on a trouvé, dans toutes les cellules étudiées, un nombre de base réduit à 59 et la présence d'un chromosome submétacentrique de type 1/29. Cette translocation toutefois n'a causé aucun désordre de la fertilité. La translocation $1 / 29$, trouvée dans la vache, a été mise en évidence chez les jumeaux aussi; chez les deux veaux nous avons trouvé, de plus, la présence d'un chimérisme leucocytaire : $59 \mathrm{XX}, 59 \mathrm{XY}$. 


\section{Riassunto \\ Una translocatione di Robertson in una vacca Chianina}

Indagini cariologiche compiute sui bovini di razza Chianina, hanno permesso di evidenziare in una vacca di 13 anni età, con una normale fertilità, $\mathrm{e}$ in due suoi figli gemelli di sesso diverso alterazioni strutturali cromosomiche.

L'abberrazione comprendente la fusione centrica di due cromosomi (translocazione 1/29) è stata riscontrata sia nella bovina che nei suoi figli che presentavano inoltre il chimerismo leucocitario $59 \mathrm{XX} / 59 \mathrm{XY}$.

\section{References}

BoIti C., 1981. Personal communication.

Bongso A., BaSRUR P.K., 1976. Chromosome anomalies in Canadian Guernsey bulls. Cornell Vet., 66, 476-488.

Casciotti D., Gamboni F., Silvestrelli M., Valfré F., 1980. Interrelazioni tra Cu,

$\mathrm{Zn} \mathrm{e} \mathrm{PGF}_{2 \alpha}$, in bovine Chianine e Frisone a differente fertilità. Atti del XII Congresso Internazionale della Società Italiana di Buiatria.

El-Nahass E., Syrjalla A., Michelmann H.W., Paufler S., 1974. Mosaik einer X-Chromosomen-Aberration als wahrscheinliche Ursache der Sterilität bei einem Rind. Dtsch. tierärztl. Wschr., 81, 397-398.

El-Nahass E., Michelmann H.W., Paufler S., 1976. Chromosomale Untersuchungen von Zucht- und Schlachtrindern, Züchtungsk., 48, 264-277.

Grouchy J. De, Roubin M., Passage E., 1964. Microtechnique pour l'étude des chromosomes humains à partir d'une culture de leucocytes sanguins. Ann. Génét. Sél. anim., 7, 45 .

Halnan C.R.E., 1972. Autosomal deletion and infertility in cattle. Vet. Rec., 91, 572.

Hanada H., Muramatsu S., 1980. A case of subfertile cow with structural abonrmalities of the X-chromosome. Ann. Génét. Sél. anim., 12, 209-213.

Succi G., De Giovanni A., Molteni L., 1976. Nouvelles observations sur une translocation robertsonienne en race bovine Romagnole. Ann. Génét. Sél. anim., 8, 37-40. 